Volume 4 Nomor 2 Ed. Desember 2018 : page 204-217

p-ISSN: $2460-805 \mathrm{X}$ e-ISSN : 2550-0295

DOI : 10.24252 /iqtisaduna.v4i2.6246

\title{
Implementasi Prinsip Good Governance Pada Lembaga Pengelolaan Zakat Baznas Kota Gorontalo
}

\author{
Sudirman \\ IAIN Sultan Amai Gorontalo \\ Jl. Gelatik No. 1 Kota Gorontalo - Gorontalo \\ E-mail : yudih65@yahoo.co.id
}

Diterima: 12 Oktober 2018; Direvisi: 11 Desember 2018; Diterbitkan: 24 Desember 2018

\begin{abstract}
Abstrak,
Penelitian ini bertujuan untuk menganalisis Implementasi Prinsip Good Governance pada Pengelolaan Zakat di Lembaga Badan Amil Zakat Nasional (BAZNAS) Kota Gorontalo. Penelitian ini adalah jenis penelitian kualitatif. Teknik pengumpulan data dilakukan melalui wawancara, observasi, dan dokumentasi. Hasil penelitian menujukkan bahwa implementasi prinsip-prinsip Good Governance di Lembaga BAZNAS Kota Gorontalo sudah cukup memadai, baik pada aspek transparansi, keadilan, dan responsibility maupun pada aspek aturan hukum. Kemudian, khusus pada aspek akuntabilitasnya belum sepenuhnya sesuai dengan Pernyataan Standar Akuntansi PSAK 02 revisi 2009. Pada penelitian ini ditemukan bahwa laporan arus kas keluar belum merujuk pada ED PSAK ditemukan bahwa BAZNAS Kota Gorontalo hanya melaporkan 2 aktivitas saja, yaitu oprerasional dan aktivitas investasi, sementara pada aspek pendanaan belum dimunculkan dalam laporan keuangan.
\end{abstract}

Kata Kunci: Zakat, Good Governance, Pengelola, Gorontalo

\begin{abstract}
,
This study aims to analyze the implementation of the principles of good governance in the management of zakat in the National Zakat Agency (BAZNAS) of Gorontalo City. This research is qualitative research. Data collection techniques are carried out through interviews, observation, and documentation. The results of the study show that the implementation of the principles of Good Governance in the BAZNAS Institute of Gorontalo City is sufficient, both in the aspects of transparency, justice, and responsibility as well as on the legal aspects. Then, specifically in the aspect of accountability, it has not been fully in accordance with the Accounting Standard Statement PSAK 02 revision 2009. In this study it was found that the cash outflow report has not referred to ED PSAK found that BAZNAS Gorontalo City only reported 2 activities, namely operational and investment activities, while in the aspect of funding has not been raised in the financial statements
\end{abstract}

Keywords: Zakat, Good Governance, Management, Gorontalo 


\section{PENDAHULUAN}

Zakat merupakan salah satu rukun Islam, sehingga wajib (fardu) ditunaikan oleh setiap setiap Muslim yang telah memenuhi syarat tertentu. Karena itu, zakat termasuk kategori ibadah yang sama pentingnya dengan ibadah-ibadah lainnya, seperti shalat, haji dan puasa. Pentingnya berzakat telah diatur secara rinci dalam Al-Quran dan As-Sunnah. Kedudukan zakat disebutkan dalam al-Qur'an Surat al-Baqarah (2):43: yang dirangkaikan dengan kata shalat yaitu "Dan dirikanlah shalat tunaikanlah zakat dan ruku'lah beserta orang-orang yang ruku” (Ataya, 2013). Zakat memiliki posisi yang penting dan strategis meningkatkan kesejahteraan umat. Ajaran berzakat memberikan landasan bagi tumbuh dan berkembangnya kekuatan sosial ekonomi umat (Abidin, 2004). Ajaran zakat meliputi beberapa dimensi, yaitu: nilai-nilai privat-publik, vertikal horizontal, serta ukhrawi-duniawi. Nilai-nilai tersebut merupakan landasan pengembangan kehidupan kemasyarakatan yang bersifat komprehensif.

Mengingat pentingnya manfaat dari zakat, maka zakat harus dikelola dengan manajemen yang baik, yaitu harus mengacu pada prinsip-prinsip syari'ah Islam agar manfaat dari zakat dapat dioptimalkan. Keberhasilan dalam pengelolaan zakat sangat ditentukan oleh peran institusi pengelola zakat yaitu Badan Amil Zakat (BAZ) yang telah didirikan oleh pemerintah, serta Lembaga Amil Zakat (LAZ) yang dikelola oleh masyarakat. Pengeloaan zakat dilaksanakan bertujuan untuk dapat meningkatkan efektifitas dan efisiensi pengelolaan zakat. Lembaga pengelolaan zakat harus dapat memaksimalkan seluruh potensi zakat yang ada dari masyarakat. Seperti yang telah dijelaskan dalam Undang-Undang Nomor 23 Tahun 2011 bahwa zakat merupakan pranata keagamaan yang bertujuan untuk meningkatkan keadilan dan kesejahteraan masyarakat. Tidak hanya undang-undang yang mengatur tentang zakat, melainkan juga terdapat Peraturan Pemerintah Nomor 14 Tahun 2014 mengenai teknis pengelolaan zakat dan Pernyataan Standar Akuntansi Keuangan (PSAK) Nomor 109 tahun 2008 dan PSAK 02 revisi tahun 2009. Lembaga pengelolaan zakat merupakan suatu institusi yang dapat menghimpun dana zakat, Infaq, dan sagaqah dari para muzakki, kemudian disalurkan kembali kepada para mustahiq dalam rangka untuk meningkatkan pendapatan, kesejahteraan serta mengurangi kemiskinan. Fungsi zakat sesungguhnya terdiri dari dua, yaitu, fungsi sosial dan fungsi spiritual. Fungsi sosialnya mengandung semangat tolong menolong, gotong royong, dan membina jalinan persaudaraan. Zakat akan membangkitkan solidaritas sosial serta mengurangi kesenjangan sosial dalam masyarakat. Kemudian, fungsi spiritualnya adalah untuk menyucikan harta dari unsur haram. Disamping itu, juga sebagai sarana untuk mendekatkan diri kepada Allah SWT. 
Dalam menjalankan fungsinya, BAZNAS Kota Gorontalo mendapatkan dukungan dari pemerintah setempat, baik melalui program sosialisasi yang dilakukan oleh instansi terkait terhadap pentingya berzakat maupun melaui kebijakan dengan memperkuat regulasi pengelolaan zakat. Mengingat besarnya manfaat dari pengelolaan zakat, maka pemerintah sangat gencar dalam melakukan pemberdayaan terkait dengan pengelolaan zakat, agar manfaat dari pengelolaan zakat dapat dioptimalkan. Oleh karena itu, Pengelolaan zakat harus dikelola secara efektif dan efisien. Badan Amil Zakat Nasional Kota Gorontalo terus berbenah dalam rangka untuk memperbaiki kinerjanya. BAZNAS Kota Gorontalo terus berupaya untuk meningkatkan penghimpunan dana zakat dari para muzakki melalui berbagai program sosialisasi dalam rangka untuk meningkatkan kesadaran masyarakat untuk memenuhi kewajiban berzakat. Di samping itu juga, berupaya meningkatkan program penyaluran dana zakat kepada masyarakat yang masuk ke dalam golongan delapan asnaf dengan berbagai jenis program kegiatan.

Tabel 1. Data Penerimaan dan Penyaluran Dana Zakat di BAZNAS

Kota Gorontalo Tahun 2017

\begin{tabular}{|c|c|c|}
\hline Bulan & Penerimaan & Penyaluran \\
\hline Januari & Rp 109.764.619 & Rp 137.523.577 \\
\hline Februari & Rp 102.971.926 & Rp 85.871.491 \\
\hline Maret & Rp 149.004.824 & Rp 21.135.203 \\
\hline April & Rp 126.452.328 & Rp 207.291.541 \\
\hline Mei & Rp 133.720.337 & Rp 193.015.042 \\
\hline Juni & Rp 577.594.740 & Rp 515.805.630 \\
\hline Juli & Rp 168.684.210 & Rp 31.285.526 \\
\hline Agustus & Rp 117.761 .818 & Rp 100.407.777 \\
\hline September & Rp 110.145.611 & $\mathrm{Rp} 114.518 .201$ \\
\hline Oktober & $\mathrm{Rp} 121.340 .950$ & Rp 150.774.119 \\
\hline November & Rp 155.356.043 & $\operatorname{Rp} 67.219 .380$ \\
\hline Desember & $\mathrm{Rp} 196.261 .124$ & Rp 307.982.641 \\
\hline Jumlah & Rp 2.069.058.530 & Rp 1.932.830.128 \\
\hline
\end{tabular}

Dari data tersebut di atas menunjukkan bahwa penerimaan zakat maupun pendistribusian zakat di Badan Amil Zakat Nasional Kota Gorontalo cenderung berfluktuasi. Kondisi ini mengindikasikan bahwa pengelolaan zakat di BAZNAS Kota Gorontalo belum optimal. Pada data tersebut, memunculkan tandatanya dalam sistem pengelolaan zakat di BAZNAS Kota Gorontalo.

Berdasarkan uraian tersebut di atas, maka peneliti tertarik untuk menganalisis penerapan Prinsip Good Governance pada Lembaga BAZNAS Kota Gorontalo. Sedangkan alasan memilih BAZNAS Kota Gorontalo, karena melihat perkembangan BAZNAS Kota 
Gorontalo saat ini sudah mengalami kemajuan dengan menerapkan apliksai terbaru dengan berbasikan website Sistem Informasi Manajemen BAZNAS (SIMBA). Selain itu, Lembaga BAZNAS Kota Gorontalo sudah menerapkan PSAK Nomor 109 tahun 2008.

Optimalisasi pengelolaan zakat akan dapat diwujudkan apabila didukung oleh sistem tata kelola yang baik. Konsep Good Governance adalah salah satu konsep tata kelolah organisasi yang sangat populer saat ini. Good governance adalah pemerintahan yang baik yaitu suatu pengelolaan lembaga yang baik dan optimal, karena di dalamnya mengedepankan prinsip Profesionalitas, Akuntabilitas, Transparansi, Keadilan dan lain-lainnya. Di samping itu, pada sistem ini pula telah mencakup mendesain sistem pengendalian intern yang cocok digunakan pada organisasi mengelolah dana publik, termasuk lembaga pengelola zakat, seperti badan amil zakat dan lembaga amil zakat (BAZ/LAZ), sebagai lembaga yang menjembatani kepentingan Muzakki dan Mustahiq.

Konsep good governance adalah salah suatu acuan untuk menjalankan operasional suatu lembaga. Prinsip good governance ini menjadi sangat penting untuk diimplementasikan di Lembaga Pengelola Zakat di BAZNAS Kota Gorontalo agar pengelolaan zakat dapat lebih optimal, akuntabel, efektif dan efisien, serta teransparan. Untuk mewujudkan cita-cita tersebut, maka sangat dibutuhkan bimbingan dan pembinaan dari pihak-pihak terkait.

\section{TINJAUAN TEORITIK}

\section{Pengertian Zakat}

Shiddieqy (2005) menyatakan bahwa zakat menurut bahasa, berarti nama (kesuburan), thaharah (kesucian), barakah (keberkatan dan berarti juga tazkiyah, tathhier (mensucikan). Adapun dalil yang membahas tentang zakat dapat dilihat dalam QS an-Nur ayat 56 :

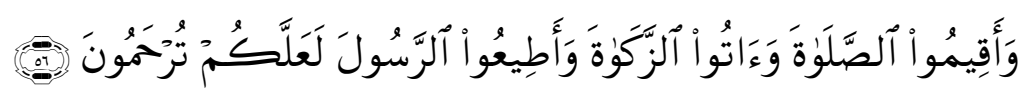

Terjemahnya:

Dan dirikanlah shalat, tunaikanlah zakat, dan taatlah kepada Rasul supaya kamu diberi rahmat.

Sedangkan Menurut istilah syara', zakat bermakna mengeluarkan sejumlah harta tertentu untuk diberikan kepada orang-orang yang berhak menerimanya (mustahik) sesuai dengan syarat-syarat yang telah ditentukan syariat Islam. Kemudian, menurut garis besarnya, zakat terbagi menjadi dua: Pertama, Zakat Mal (harta): emas, perak, binatang, tumbuh-tumbuhan (buah-buahan dan biji-bijian) dan barang perniagaan; kedua, Zakat Nafs, zakat jiwa yang 
disebut juga "Zakatul Fithrah". (zakat yang diberikan berkenaan dengan selesainya mengerjakan shiyam (puasa) yang difardlukan).

Adapun Lembaga Pengelolaan zakat (LPZ) di Indonesia adalah Badan Amil Zakat (BAZ) dan Lembaga Amil Zakat (LAZ). Lembaga pengelolah zakat merupakan institusi yang bertugas dalam pengelolaan zakat, infaq, dan shadaqah, baik yang dibentuk oleh pemerintah seperti BAZ, maupun yang dibentuk oleh masyarakat dan dilindungi oleh pemerintah seperti LAZ. Aktivitas pngelolaan zakat meliputi: perencanaan, pelaksanaan, dan peng-koordinasian dalam pegumpulan, pendistribusian, dan pendayagunaan zakat. Pengelolaan zakat harus mengacu pada peraturan perundang-undangan yang telah dibuat oleh pemerintah. Terdapat beberapa pedomaan dalam pengelolaan zakat yang diterapkan pada BAZNAS Kota Gorontalo, yaitu; Undang-Undang No. 23 Tahun 2011 tentang pengelolaan zakat; Peraturan Pemerintah (PP) No. 14 Tahun 2014 tentang pelaksanaan Undang-undang No. 23 Tahun 2011 tentang pengelolaan zakat; PERDA (Peraturan Daerah) No. 10 Tahun 2008 tentang pemotongan zakat pada pegawai negeri Kota Gorontalo; Petunjuk pelaksanaan BAZNAS Pusat tentang SIstem Informasi Manajemen BAZNAS (SIMBA). Pernyataan Standar Akuntansi Keuangan (PSAK) No. 109 Tahun 2008 dan revisi PSAK 02 Tahun 2009.

\section{Pengertian Good Governance}

Secara konseptual "good" dalam bahasa Indonesia "baik" dan "Governance" adalah "kepemerintahan" (Anonim, 2013). Good governance diartikan sebagai tata tingkah laku atau tindakan yang baik yang didasarkan pada kaidah-kaidah tertentu untuk pengelolaan masalahmasalah publik dalam kehidupan keseharian (Gatara dan Sofhian, 2012). Dengan demikian good and governance adalah pemerintahan yang baik dalam standar proses dan hasilhasilnya, semua unsur pemerintahan bisa bergerak secara sinergis, tidak saling berbenturan, memperoleh dukungan dari rakyat dan terlepas dari gerakan-gerakan anarkis yang dapat menghambat proses pembangunan (Sulaiman, 2013).

\section{Prinsip-Prinsip Good Governance}

Pengertian good governance adalah penyelenggaraan pemerintahan negara yang solid dan bertanggung jawab, serta efisien dan efektif dengan menjaga "kesinergian" interaksi yang konstruktif di antara domain-domain negara, sektor swasta dan masyarakat (society). Dalam Peraturan Pemerintah Nomor 101 Tahun 2000 dan kepemerintahan yang baik (good governance) menurut Badan PBB untuk pembangunan atau UNDP prinsip-prinsip kepemerintahan yang baik terdiri dari (Rohman, 2000): 
Terdapat beberapa indikator yang dapat digunakan dalam mengukur Good Governance menurut UNDP yaitu: Profesionalitas, Efektif, Efisien, Akuntabilitas, Keadilan, Responsibility dan Aturan Hukum.

Profesionalitas, meningkatkan kemampuan dan moral penyelenggaraan pemerintahan agar mampu memberi pelayanan yang mudah, cepat, tepat dengan biaya yang terjangkau.

Akuntabilitas, meningkatkan akuntabilitas para pengambil keputusan dalam segala bidang yang menyangkut kepentingan masyarakat.

Transparansi, menciptakan kepercayaan timbal balik antara pemerintah dan masyarakat melalui penyediaan informasi dan menjamin kemudahan di dalam memperoleh informasi yang akurat dan memadai.

Berkeadilan (Equity), Pemerintahan yang baik akan memberikan kesempatan yang sama terhadap semua pihak, baik laki-laki maupun perempuan dalam upaya untuk meningkatkan dan memelihara kualitas hidupnya.

Daya Tanggap (Responsiveness). Setiap institusi dan prosesnya harus diarahkan pada upaya untuk melayani berbagai pihak yang berkepentingan (stakeholders).

Efisiensi dan Efektifitas, menjamin terselenggaranya pelayanan kepada masyarakat dengan menggunakan sumber daya yang tersedia secara optimal dan bertanggung jawab.

Aturan Hukum (Rule of Law), kerangka aturan hukum dan perundang-undangan harus berkeadilan, ditegakkan dan dipatuhi secara utuh tanpa memihak kepada siapapun (impartially), terutama aturan hukum tentang hak asasi manusia.

\section{METODE PENELITIAN}

\section{Desain Penelitian}

Penelitian ini adalah merupakan jenis penelitian deskriptif dengan pendekatan kualitatif murni. Pada penelitian ini, peneliti akan mendeskripsikan konsep system manajemen pengelolaan zakat, infaq, dan shodaqoh yang telah diterapkan pada lembaga BAZNAS Kota Gorontalo. Kemudian, pada tahap berikutnya, peneliti melakukan proses konfirmasi antara data-data yang berkaitan dengan system manajemen pengelolaan Zakat, Infaq, dan Shodaqoh pada Lembaga Badan Amil Zakat Kota Gorontalo dengan Konsep Good Governance yang telah dikemukakan oleh para ahli.

\section{Jenis dan Sumber Data}

Jenis dan sumber data yang digunakan pada penelitian ini adalah data primer dan data sekunder. Data primer adalah merupakan data yang diperoleh secara langsung melalui 
wawancara kepada pengurus (Komisioner) lembaga BAZNAS Kota Gorontalo. Sedangkan data sekunder adalah data yang diperoleh melalui studi kepustakaan, yaitu berupa Laporan Keuangan maupun Flow chart sistem pencatatan arus kas pada Lembaga BAZNAS Kota Gorontalo.

\section{Teknik Pengumpulan Data}

Adapun metode pengumpulan data yang digunakan pada penelitian ini adalah dokumentasi, observasi, dan wawancara. Dokumentasi yaitu pengumpulan data yang dilakukan dengan melihat Laporan Keuangan maupun dokumen-dokumen lainnya yang berkaitan dengan penelitian ini. Observasi (pengamatan langsung) peneliti mengamati beberapa gambar atau Flow chart yang dipajang di beberapa tempat, yang merupakan petunjuk dalam memahami sistem pengelolaan zakat, infaq dang sadaqah di BAZNAS Kota Gorontalo. Sedangkan wawancara dengan berbagai pihak terkait, terutama pada pihak-pihak yang terlobat langsung dalam sistem pengelolaan penerimaan dan penyaluran zakat di lembaga BAZNAS Kota Gorontalo.

\section{Analisis Data}

Metode analisis yang digunakan pada penelitian ini adalah analisis deskriptif kualitatif, yaitu mendeskripsikan berbagai data yang berkaitan dengan manajemen pengelolaan Zakat, Infaq, dan Sadaqah. Pada penelitian ini, peneliti mencoba melakukan proses konfirmasi terhadap konsep manajemen Good Governance. Langkah-langkah yang dilakukan dalam proses analisis data adalah peneliti membuat display (tampilan) data melalui tiga alur kegiatan, yaitu Reduksi data (data reduction); dalam hal ini, peneliti merangkum memilih hal-hal yang pokok, memfokuskan pada hal-hal yang penting pada catatan tertulis yang diperoleh dari lapangan.

Penyajian data(data display); setelah data direduksi, maka langka selanjutnya adalah menyajikan data. Penyajian data yang dilakukan oleh peneliti adalah dalam bentuk uraian singkat, berupa penyajian data dalam bentuk tabel, maupun dalam bentuk narasi. Namun sebelum itu, data yang telah dikumpulkan dilakukan penyuntingan, kemudian diidentifikasi, dikategorikan, dianalisis, dan kemudian mengungkapkan system manajemen pengelolaan Zakat, Infaq, dan Shodaqoh. serta memberikan kesimpulan.

Penarikan kesimpulan dan verifikasi (congclution drawing/verification); pada tahap ini, kesimpulan awal yang dikemukakan masih bersifat sementara dan akan berubah bila ditemukan bukti-bukti yang kuat mendukung pada tahap pengumpulan data berikutnya. Akan tetapi apabila kesimpulan yang diambil pada tahap awal didukung didukung oleh bukti- 
bukti yang valid dan konsisten saat peneliti kembali kelapangan untuk menyimpulkan data, maka kesimpulan yang dikemukakan merupakan kesimpulan yang kredibel.

\section{HASIL DAN PEMBAHASAN}

Pada penelitian ini ditemukan bahwa penerapan prinsip-prinsip good governance pada lembaga BAZNAS Kota Gorontalo sudah cukup memadai. Petugas pengelola zakat telah berusaha untuk bersikap profesional dalam melaksanakan tugasnya, yaitu mereka senantiasa bekerja sesuai dengan kewenangan yang telah diberikan dan dilaksanakan dengan penuh tanggung jawab. Para petugas pengelolah Zakat memiliki komitmen yang tinggi untuk melakukan yang terbaik, yaitu mereka selalu berupaya untuk menjunjung tinggi sikap profesionalitas, transparansi, dan akuntabilitas serta prinsip manajemen yang baik. Kondisi tersebut, dapat dilihat dari pelaksanaan beberapa komponen prinsip Good Governance yang telah dilaksanakan dengan sebagaimana mestinya. Menurut Boi Mz Soujiro (dalam Sagara), profesionalitas adalah kompetensi untuk melaksanakan funsinya secara baik dan benar dan juga komitmen dari para anggota dari sebuah profesi untuk meningkatkan kemampuan dari seorang karyawan atau pegawai. Sementara professional mempunyai arti seorang yang trampil, handal, dan sangat bertanggung jawab dalam menjalankan tugasnya: Istilah profesional itu berlaku untuk semua aparat mulai dari tingkat atas sampai tingkat bawah. Profesionalisme dapat diartikan sebagai suatu kemampuan dan keterampilan seseorang dalam melakukan pekerjaan menurut bidang dan tingkatan masing-masing.

Selanjutnya, aspek efektifitas. Pada penelitian ini dapat pula dikatakan bahwa pengelolaan zakat pada Lembaga Badan Amil Zakat Kota Gorontalo sudah dapat dikatakan berjalan efektif, karena mereka telah melakukan pengelolaan zakat dengan sebagaimana mestinya, yaitu pengelolaan dana zakat dapat dikelola dengan baik berdasarkan dengan prinsip-prinsip syariah. Konsep efektif sesungguhnya adalah kemampuan untuk menyelesaikan pekerjaan dengan baik dan benar, yaitu sesuai dengan tata aturan atau pedoman yeng telah disiapkan. Menurut Hidayat (1986), Efektivitas adalah suatu ukuran yang menyatakan seberapa jauh target (kuantitas, kualitas dan waktu) telah tercapai. Dimana makin besar persentase target yang dicapai, makin tinggi efektivitasnya. Kemudian, pada aspek efisiensi pengelolaan zakat pada BAZNAS Kota Gorontalo juga sudah dapat dikatakan efisien, karena mereka tidak memiliki biaya operasional yang relative sangat kecil, sehingga mereka selalu berupaya mengoptimalkan penggunaan biaya, waktu dan tenaga pada setiap kegiatan. Pengertian efisien dalam Kamus Besar Bahasa Indonesia adalah ketepatan cara (usaha, kerja) dalam menjalankan sesuatu dengan tidak membuang waktu, tenaga, dan biaya. 
Transparancy (keterbukaan), untuk meningkatkan semangat keterbukaan, maka pengelolaan zakat pada lembaga BAZNAS Kota Gorontalo diterapkanlah Sistem Informasi Manajemen (SIMBA). Pada penelitian ini ditemukan bahwa pengelolaan zakat di lembaga BAZNAS Kota Gorontalo sudah dilakukan secara transparan. Laporan keungan pada lembaga BAZNAS kota Gorontalo selalu dipublikasikan kepada masyarakat secara berkala melalui media cetak maupun melalui website. Setiap pengelolaan dana zakat selalu disertai dengan SPJ (Surat Pertanggung Jawaban) dengan melampirkan semua bukti penerimaan maupun pengeluaran yang telah disepakati dalam rapat komisioner.

Di samping itu, informasi laporan keungan selalu diaudit secara berkala. Oleh karena itu, kondisi tersebut sudah sesuai dengan prinsip transparansi yang telah kemukakan oleh Lalolo, yaitu terpenuhinya prinsip yang menjamin akses atau kebebasan bagi setiap orang untuk memperoleh informasi tentang penyelenggaraan pemerintahan, yakni informasi tentang kebijakan, proses pembuatan serta hasil yang dicapai (Putra, 2014). Dengan Indikator Transparansi menurut Krina: Penyediaan informasi yang jelas tentang prosedur-prosedur, biaya-biaya dan tanggung jawab, kemudahan akses informasi dan lainnya.

Aspek akuntabilitas, pada penelitian ini ditemukan bahwa sistem pengelolaan dan pencatatan keuangan pada lembaga BAZNAS kota gorontalo telah mengacu pada Pernyataan Standar Akuntansi Keuangan (PSAK) Nomor 109 tahun 2008. Sistem tersebut, telah berbasis aplikasi dan didukung dengan sistem jaringan online, sehingga memudahkan oleh setiap pengguna informasi untuk mengakses laporan keuangan yang telah disajikan. Pertanggungjawaban pengelolaan dana zakat dilaporkan berdasarkan jenis kegiatan yang telah dilakukan. Kemudian, pada setiap laporan kegiatan harus dilengkapi dengan bukti-bukti dokumen pendukung. Selanjutnya, amil membuat laporan pertanggungjawaban dari seluruh kegiatan bulanan, meliputi neraca dan laporan arus kas masuk dan arus kas keluar. Laporan tersebut diaudit secara berkala. Laporan keuangan yang telah disusun selalu dipublikasikan melalui media cetak maupun website lembaga.

Walaupun laporan keuangan pada BAZNAS gorontalo telah mengacu pada PSAK 109 tahun 2008, akan tetapi untuk laporan arus arus kas keluar harus mengacu pada ED PSAK 02 revisi tahun 2009. Berdasarkan ED PSAK 02 revisi tahun 2009 aktivitas arus kas dibagi menjadi 3 yaitu aktivitas operasional, aktivitas investasi, dan aktivitas pendanaan. Sementara BAZNAS Kota Gorontalo hanya melaporkan 2 aktivitas saja, yaitu oprerasional dan aktivitas investasi, sehingga laporan arus kas keular oleh BAZNAS Kota Gorontalo belum sesuai dengan sebagaimana mestinya, karena jika merujuk pada ED PSAK 02 revisi tahun 2009. Laporan arus kas keluar dibagi menjadi 3 yaitu aktivitas operasional, aktivitas investasi, dan aktivitas pendanaan. Pendanaan untuk fasilitas publik atau infrastruktur telah menjadi program 
pembangunan oleh pemerintah daerah, sehingga lembaga BAZNAS tidak fokus ke sector tersebut. Karena itu, laporan arus kas keluar oleh BAZNAS Kota Gorontalo tidak muncul laporan dari aktivitas pendanaan. Lembaga BAZNAS Kota Gorontalo belum menemukan objek yang tepat untuk melakukan aktivitas pendanaan. Namun demikian, system pencatatan laporan keuangan sudah mengacu pada PSAK Nomor 109 tahun 2008. Sejalan dengan itu, maka dapat dikatakan bahwa pengelola keuangan pada BAZNAS Kota Gorontalo sudah baik dan transparan, sehingga cukup refresentatif untuk dijadikan bahan rujukan mengevaluasi kinerja para pengelolah BAZNAS Kota Gorontalo.

Lembaga BAZNAS Kota Gorontalo telah memiliki pertanggungjawaban (akuntabilitas) kepada publik (masyarakat umum), sebagaimana halnya kepada para pemilik (stakeholders). Sistem pengelolaan zakat terdiri dari prosedur penerimaan zakat, prosedur pengeluaran zakat dan prosedur pelaporan zakat untuk publik. Proses penerimaan zakat meliputi proses mengatur bagian penerimaan zakat serta mencatatnya dalam buku sumber penerimaan zakat. Sebaliknya, prosedur pengeluaran zakat menggambarkan alur bagian pengeluaran ketika mengeluarkan Dana zakat dan mencatatnya dalam buku pengeluaran zakat. Sejak berstatus sebagai Badan Amil Zakat Daerah (BAZDA), pendistribusian dilakukan rutin setiap bulannya, namun setelah menjadi Badan Amil Zakat Nasional Kota Gorontalo (BAZNAS) hanya melakukan pendistribusian 2-3 bulan sekali. Badan Amil Zakat Nasional Kota Gorontalo tahunnya melaporkan laporan keuangan melalui media cetak radar Gorontalo.

Selanjutnya, pada aspek penyeluran dana zakat, infaq, dan sadaqa sudah sesuai dengan apa yang telah dianjurkan, meliputi delapan asnaf, yaitu, Fakir, Miskin, Amil Zakat, Mu'allaf, Budak, orang yang berutang, Fisabilillah, dan Musafir. Pendistribusian Dana zakat oleh Lembaga BAZNAS Kota Gorontalo dilakukan melalui tiga bentuk, yaitu; pertama dana disalurkan kepada mustahiq sebagai dana konsumtif; kedua dana dialurkan kepada mustahiq sebagai dana produktif; dan ketiga, sebagai pendanaan. Dana konsumtif diberikan untuk kebutuhan konsumsi langsung sedangkan dana produktif diberikan dengan tujuan untuk dikelola sebagai tambahan modal kerja dalam rangka untuk meningkatkan produktifitas usaha yang yang digeluti oleh setiap muzakki. Kemudian, untuk penyaluran dana untuk pendanaan dilakukan apabila ada sebuah aktivitas oleh mustahiq yang sangat memungkinkan untuk didanai. Seperti, penyaluran beasiswa, pelatihan life skill, serta membangun fasilitas untuk digunakan oleh para mustahiq.

Uraian tersebut di atas, sudah sejalan dengan teori yang telah dikemukakan oleh David Hulme dan Mark Turney, bahwa akuntabilitas merupakan suatu konsep yang kompleks yang memiliki beberapa indikator. Indikator akuntabilitas Menurut Elwood, akuntabilitas hukum, yaitu harus patuh terhadap hukum, penghindaran korupsi dan kolusi; 
Akuntabilitas proses, dimana adanya kepatuhan terhadap prosedur. Kemudian, pelayanan publik yang responsive dan lain sebagainya (Garini, 2011).

Selanjutnya, Aspek keadilan. Jika dikaitkan dengan kaidah syariat Islam bahwa yang berhak menerima zakat, infaq, dan sadaqah adalah ke delapan asnaf, maka dapat dikatakan bahwa pada lembaga BAZNAS kota Gorontalo belum memenuhi, karena dapat dilihat dari bagaimana lembaga itu menyalurkan dana zakat kepada orang-orang yang berhak menerimanya yaitu delapan Asnaf. Pada lembaga BAZNAS Kota Gorontalo terdapat dua Asnaf yang tidak dilaksanakan yaitu budak dan orang yang berhutang. Pendistribusiannya lebih diutamakan kepada fakir, dan miskin. Hal ini jika dikaitkan dengan teori yang telah dikemukakan oleh Thomas Hobbes: "Suatu perbuatan dikatakan adil apabila telah didasarkan pada perjanjian-perjanjian atau kaidah-kaidah tertentu. Artinya, seseorang yang berbuat berdasarkan perjanjian atau peraturan yang berlaku." indikatornya yaitu, distribusi yang adil atas sumber daya ekonomi, sosial, hukum, dan sebagainya. Kemudian, adanya afirmatif (diskriminasi positif) untuk masyarakat marjinal atau miskin demi mewujudkan keadilan sosial dan lainnya.

Mengenai kejelasan tanggung jawab dalam lembaga BAZNAS Kota Gorontalo, yaitu telah disesuaikan dengan bidangnya masing-masing artinya, para pengurus lembaga zakat akan bertanggungjawab (responsibility) pada setiap bidang masing-masing yang telah didelegasikan oleh pimpinan lembaga. Tingginya rasa tanggung jawab dan kepedulian akan mendorong mereka untuk bekerja dengan lebih baik. Semangat tersebut didukung dengan kondisi sumber daya manusia yang sudah relative terlatih dan trampil. Di samping itu, pimpinan lembaga juga selalu berupaya mendisiplinkan para anggotanya dengan mengaktifkan absensi jam masuk dan pulang kerja. Menurut Friedrick, bahwa untuk mencapai standar profesionalisme, maka setiap administrator harus memiliki kompetensi yang memadai dalam menjalankan tugasnya. Responsibilitas merupakan standar dalam pengukuran kualitas dari sebuah pelayanan publik. Indikator responsibilitas yaitu, kejelasan tanggung jawab dan wewenang, memiliki komitmen untuk melaksanakan tanggung jawab dan wewenang, memiliki kebijakan pengelolaan keuangan (Dwiyanto, 2006).

Peraturan hukum di Lembaga BAZNAS Kota Gorontalo sudah berjalan dengan baik dan di patuhi seluruh amil zakat. Para amil selalu berupaya menaati peraturan yang berlaku, baik terhadap regulasi yang telah dibuat oleh pemerintah daerah maupun regulasi yang dibuat oleh pemerintah pusat. Pemerintah pusat telah menerbitkan UU tentang BAZNAS Nomor 1 Tahun 2016 tentang Pedoman Rencana Kerja dan Anggaran Tahunan (RKAT) BAZNAS baik BAZNAS Provinsi, BAZNAS Kabupaten/Kota seluruh pekerjaan kerja dan anggaran BAZNAS, adanya pertanggungjawaban berdasarkan Undang-Undang Nomor 23 tahun 2011 dan 
Peraturan Pemerintah Nomor 14 Tahun 2014, dan adanya peraturan Pernyataan Standar Akuntansi Keuangan (PSAK) Nomor 109 dalam pengelolaan zakat. Kemudian, Pemerintah daerah telah menerbitkan Peraturan Wali Kota (PERWAKO) tentang pengaktifan lembaga pengelolaan zakat (BAZNAS) di Kota Gorontalo.

\section{KESIMPULAN}

Penerapan prinsip Good Governance pada Badan Amil Zakat Nasional Kota Gorontalo sudah cukup memadai. Hal tersebut, dapat dilihat dari pencapaian dari penerapan pada seluruh komponen dari indikator prinsip Good Governance, yaitu melipu; aspek profesionalitas, efektifitas, akuntabilitas, transparansi, sudah berjalan relative cukup bagus. Namun pada aspek keadilan, belum sepenuhnya berjalan dengan baik, karena pada lembaga BAZNAS Kota Gorontalo belum sepenuhnya menyalurkan dana zakat berdasaarkan ke 8 Asnaf. Terdapat 2 Asnaf yang tidak dilaksanakan, yaitu budak dan orang yang berhutang. Pendistribusian dana zakat lebih diprioritaskan kepada fakir dan miskin.

Pada Lembaga BAZNAS Kota Gorontalo melaksanakan aktivitasnya berdasarkan peraturan UU tentang BAZNAS No. 1 Tahun 2016 tentang Pedoman Rencana Kerja dan Anggaran Tahunan (RKAT) BAZNAS baik BAZNAS Provinsi, BAZNAS Kabupaten/Kota seluruh pekerjaan kerja dan anggaran BAZNAS, adanya pertanggungjawaban berdasarkan UU Nomor 23 tahun 2011, PP Nomor 14 Tahun 2014, dan adanya peraturan Pernyataan Standar Akuntansi Keuangan (PSAK) Nomor 109 dalam pengelolaan zakat.

\section{DAFTAR PUSTAKA}

Ataya, Abu Arkan Kamil. 2013. Antara Zakat Infaq dan Sedeqah. Bandung: Angkasa.

Abidin, Hamid. 2004. Reinterpretasi Pendayagunaan Zakat. Jakarta: Piramedia.

Republik Indonesia, Undang-Undang No. 23 Tahun 2011 tentang Zakat, Pasal 8 dan Pasal 9. Shiddieqy, Teungku Muhammad Hasbi Ash. 2005. Pedoman Zakat Cet. IX. Semarang: PT. Pustaka Rizki Putra.

Republik Indonesia, Undang-Undang Nomor 23 tahun 2011 tentang Pengelolaan Zakat, Pasal 1 ayat 1.

Gatara, Asep Sahid dan Subhan Sofhian 2012. Pendidikan Kewarganegaraan. Bandung: Fokus Media.

Sulaiman, Asep. 2012. Pendidikan Pancasila dan Kewarganegaraan. Bandung: Fadillah Press. 
Rochman, Meuthia Ganie. 2000. "Good governance: Prinsip, Komponen dan Penerapannya”. HAM: Penyelenggaraan Negara Yang Baik \& Masyarakat Warga. Jakarta: Komnas HAM.

Rononosumitro, Mansur. 2018. Wawancara di Lembaga Pengelola Zakat BAZNAS Kota Gorontalo, 5 Januari 2018.

Putra, Hendra G. 2014. "Pengaruh Akuntabilitas, Transparansi dan partisipasi Publik terhadap Kinerja Organisasi Layanan Publik”. Jurnal Akuntansi. Vol. 2 No.3.

Garini, India. 2011. "Pengaruh Transparansi dan Akuntabilitas terhadap kinerja Instansi Pemerintah Pada Dinas di Kota Bandung”. Skripsi. Universitas Komputer Indonesia Bandung. 
Implementasi Prinsip Good Governance Pada Lembaga Pengelolaan

Zakat BAZNAS Kota Gorontalo

Sudirman

DOI : $\operatorname{xxxxxxx}$ 